\title{
Editorial
}

\section{INTERNET PIRACY AND THE EUROPEAN POLITICAL AND LEGAL ORDERS}

One of the most remarkable results of the elections for the European Parliament on 4-7 June 2009 is that the Swedish Piratpartiet won one seat, to which another will be added if the Treaty of Lisbon enters into force. One of the aims of this party is a reform of copyright law to restore the, in its eyes, lost balance between the potentially conflicting interests of creating and spreading culture. The party strives for, among other things, the decriminalisation of all non-commercial copying and use of copyrighted material on the internet. ${ }^{1}$

Although it does not imply decriminalisation of internet piracy, the Piratpartiet without doubt will have celebrated the ruling of the French constitutional court, the Conseil constitutionnel, of 10 June 2009. With it, the constitutional council has sent a signal that has been heard all over Europe and that, so it seems, cannot be neglected by European politics and other European courts, the Court of Justice and the European Court of Human Rights included. The ruling is only the preliminary end of a fascinating European legislative episode. In a nutshell it goes like this.

In the summer of 2008, the French government, under personal supervision of the president of the Republic Nicolas Sarkozy, introduced a bill 'favorisant la diffusion et la protection de la création sur internet', nicknamed 'loi HADOPI'. It would be adopted by the French parliament in May 2009. To combat violations of copyright law via the internet, which in France are at least as widespread as in other European countries and the United States, the act created an administrative (non-penal) obligation for internet connection owners to safeguard that the use of their connection does not lead to a violation of copyrights by, e.g., the illegal reproduction and representation of copyrighted material. The act also instituted a Haute autoritépour la diffusion des oewvres et la protection des droits sur internet (HADOPI). A commission of this independent government agency was empowered to sanction infractions of the aforementioned surveillance obligation via a 'three strike procedure'. If in a period of six months after a first warning by e-mail, the connection owner was suspected of repeating the infraction of the surveillance obli-

\footnotetext{
${ }^{1}<$ www.piratpartiet.se/international/english>.
} 
gation, HADOPI could send a second warning email accompanied by a certified letter. If within a year after this second warning the connection owner again was suspected of repeating the infraction, the agency, after a contradictory procedure, was allowed to order the disconnection of the owner from the internet for a period ranging from two months to one year.

The bill was fiercely debated, not only in the French parliament, but also in French society and abroad, especially all over the net. In the late summer of 2008, the theatre of battle moved from Paris to Brussels and Strasbourg. On 24 September of that year, the European Parliament, in its first reading of the first of the proposed directives of the so-called 'Telecoms Package', ${ }^{2}$ accepted an amendment presented by Daniel Cohn-Bendit and Guy Bono, MEPs for opposition parties in France. This by now famous Amendment 138 held that 'no restriction may be imposed on the fundamental rights and freedoms of end-users, without a prior ruling by the judicial authorities, notably in accordance with Article 11 of the Charter of Fundamental Rights of the European Union on freedom of expression and information, save when public security is threatened in which case the ruling may be subsequent.'

Knowing his anti-piracy bill was in danger, Sarkozy on 4 October 2008 sent a letter to Commission president Barroso, published in Libération of 6 October 2008, asking his personal help in the defusing of the time bomb:

Il est (...) crucial que la Commission soit très vigilante face aux menaces qui se manifestent au Parlement européen à l'occasion du vote du troisième 'paquet telecom'. Il est notamment fondamental que l'amendement nº138 adopté par le Parlement européen soit rejeté par la Commission. Cet amendement tend à exclure la possibilité pour les Etats membres d'appliquer une stratégie intelligente de dissuasion du piratage. Pour écarter l'amendement, je sollicite votre engagement personnel et celui de la Commissaire en charge du dossier.

However, the Commission decided to accept Amendment 138. In its common position, the Council of Ministers then deleted it on its own (COD 2007/0247, 16496/1/2008). The European Parliament, however, in its second reading of the aforementioned Directive proposal, readopted the amendment, which by now had become amendment number 46, on 6 May 2009.

Back to Paris. After the adoption of the 'loi HADOPI' by the French Parliament on 13 May 2009, the parliamentary opposition seized the Conseil constitutionnel.

\footnotetext{
${ }^{2}$ Proposal for a directive of the European Parliament and of the Council amending Directives $2002 / 21 / E C$ on a common regulatory framework for electronic communications networks and services, 2002/19/EC on access to, and interconnection of, electronic communications networks and associated facilities, and 2002/20/EC on the authorisation of electronic communications networks and services (16496/1/2008 - C6-0066/2009 - 2007/0247(COD))
} 
The constitutional court on 10 June 2009 ruled that the act violated the French Constitution on two counts. The act violated the presumption of innocence in Article 9 of the Declaration of Rights of Man and Citizens of 1789. Instead of HADOPI having to prove the 'guilt' of the suspected owner of an internet connection, the burden of proof was placed on the owner, who had to prove that the violation of the copyrights law was due to fraud by a third party to be exonerated. The act also violated the freedom of expression and communication in Article 11 of the Declaration of 1789, a freedom which is 'all the more precious as its exercise is a condition for democracy and of the guarantees for respect of other rights and liberties.' In a very principled consideration, the Conseil constitutionnel declared that this freedom 'in the current state of affairs of communication resources and in view of the general development of public internet services as well as the importance of these for the participation in democratic life and the expression of ideas and opinions, includes the freedom of access to such services.'

The nature of the sanction powers attributed to HADOPI, their personal scope (they extended to la totalité de la population) and their effects (they could even lead to restrictions on the exercise of the freedom of expression of persons in their homes), subsequently led the Conseil constitutionnel to the finding that, in view of the nature of the freedom involved and whatever the guarantees given, the legislature was not allowed to attribute the powers described to an independent government agency in order to protect the rights of copyright holders. ${ }^{3}$ In this way the Conseil constitutionnel constitutionalised the right of access to the internet, which may only be limited after the intervention of a court.

What does this episode show us? First it shows that the European Parliament is not always as remote from the European citizens as its critics say, and that it is able to pick up on the winds stirring society. It also shows that the European Parliament is perfectly capable of taking politically sensitive and very principled positions. In this context, one wonders if an often-invoked weakness in the powers of the Parliament is at least not sometimes a blessing in disguise. As is well-known, in a parliamentary system the relationship of confidence between parliament and the government (or cabinet), according to which the government is accountable to parliament and the latter can send the former home by accepting a motion of no confidence, is supposed to give parliament grip on and in the end the upper hand over the government. But we also know that in current reality, it is more or less the other way around. The dependence of the government on parliamentary confidence is for the government a means of establishing dominion over parliament and of forcing the parliamentary majority into discipline, in its purest form

\footnotetext{
${ }^{3}$ Conseil constitutionnel 10 June 2009, decision 2009-580 DC, points 12-16.
} 
by putting a motion of confidence. Both aspects are missing on the European plane. The European Parliament can send the Commission home, but not the 'real' Union executive, the European Council and the Council of Ministers. At the same time, however, not only can the European Parliament not be dissolved, it cannot be politically forced to align to government positions either in the same way as the national parliaments of the member states are. This gives the European Parliament a freedom of position and action that is hardly encountered in any other European parliament today. This independence might be one the ways of attracting public attention and confidence.

The episode also shows, once again, that the political systems of the European Union and its member states have become entangled. In this instance, the battle that the French opposition could not win in the French Parliament was moved to Brussels and Strasbourg. There it turned into a battle between the European Parliament on the one hand and the Council of Ministers, the French president, government and the French parliament on the other. It was finally decided by the French constitutional court, which, in political terms, decided in favor of the French opposition, the European Parliament and the European Commission (the Commission welcomed the 'clarification' from the 'wise men' of the Conseil constitutionnel; Le Monde, 11 June 2009). One wonders what the impact the Conseil constitutionnel's ruling will have on the further decision-making regarding the proposed 'Telecoms Package'. Will the Council of Ministers not feel obliged to give up its resistance to what was formerly Amendment 138?

Finally, the Conseil constitutionnel, by making a constitutional right of access to the internet, has set a standard that cannot easily be neglected by the other European courts. Of course, the Court of Justice and the European Court of Human Rights, just to name two examples, are not legally bound by the decision. But it seems hardly feasible that they, if they are ever confronted with legislation similar to the 'loi HADOPI', will adopt a fundamentally different approach.

JHR/WTE 